\title{
ZHONG YONG - KILKA UWAG O ZNACZENIU I TŁUMACZENIU TYTUŁU
}

\author{
The central question for Chinese philosophers is always \\ "how should we live our lives" \\ and not "what is out there" \\ - Ni Peimin
}

\section{ZHONG YONG - A FEW REMARKS ON THE MEANING AND TRANSLATION OF THE TITLE}

\begin{abstract}
A bstract. Zhong Yong - one of the Four Books of Confucian philosophy - presents various and complicated concepts of early Chinese philosophy in the form of a guideline for people who aspire to become a sage. Zhong Yong's ambiguity is obvious; not only the main idea of integrity or sincerity - cheng - but also the concepts of zhong and yong, which separately and together provide a perplexing problem for translators. The main aim of this article is to analyse the contents of these self-development guidelines, as well as to propose an interpretation of the two terms zhong and yong, and their meaning as a phrase. I argue that the traditional translation - the Doctrine of the Mean - is inaccurate, not only because it omits the meaning of yong, but because it also does not comply with the relativist- and context-oriented thought of Early Confucian masters.
\end{abstract}

Keywords: early Confucian thought; Zhong Yong; Doctrine of Mean; self developement, Confucian religious experience.

Zhong Yong, trzydziesty pierwszy rozdział Liji-Zapisków o Rytuale, to skomplikowany tekst, który składa się z wywodu filozoficznego dotyczącego właściwego sposobu funkcjonowania społeczności oraz opisu doświadczenia religijnego ${ }^{1}$, które jest obecne w życiu konfucjańskiego mędrca shengren.

Dr Katarzyna Pejda - Katolicki Uniwersytet Lubelski Jana Pawła II, Wydział Nauk Humanistycznych, Instytut Literaturoznawstwa, II Katedra Sinologii; adres do korespondencji email: katarzynapejda@gmail.com; ORCID: https://orcid.org/0000-0003-3091-0534.

${ }^{1}$ Robert R. Marett uznał, że „doświadczenie religijne to uczucie i przeżycie nadprzyrodzoności, której człowiek się lęka, ale z którą pragnie nawiązać kontakt”. Według niego istotą i podstawą religii było uczucie, z której rodzi się rytuał. Rudolf Otto, podobnie jak Marett, 
Wraz z Najwyższą Nauką Da Xue, Analektami Konfucjusza oraz tekstem Mengzi, przypisywanym myślicielowi o tym samym nazwisku, Zhong Yong wszedł w skład Czteroksięgu Konfucjańskiego. Teksty Konfucjusza i Mencjusza stanowią uzupełniającą się myśl społeczno-polityczną, przy czym Mencjusz rozwinął teorię natury xing oraz czterech pojęć - ren, yi, li oraz $z h i$, nadając im znaczenie cech charakteru i odchodząc od relacyjnej klasterowej koncepcji ren przedstawionej w Analektach (Pejda, Reinterpretacja). Da Xue to z kolei stosunkowo prosty wywód, który przedstawia właściwą kolejność zaprowadzania ładu moralnego (ming de) w państwie i społeczeństwie. Nie można powiedzieć tego samego o Zhong Yong, który omawia wiele powiązanych ze sobą, klasterowych pojęć, wprowadzając także koncepcję cheng, która wprawdzie pojawia się w tekście Mengzi, ale ma tam o wiele prostsze znaczenie.

W pierwszej części niniejszego artykułu przedstawię analizę struktury i znaczenia całości tekstu. W drugiej zaś części zajmę się znaczeniem terminów, które znalazły się w tytule rozdziału - zhong oraz yong. Fraza zhong yong zwykle jest thumaczona jako Doktryna Środka (ang. Doctrine of Mean) - uważam ten przekład za nieadekwatny, dlatego w podsumowaniu podam i uzasadnię własną interpretację tej frazy. James Legge przyznał, że przy tłumaczeniu tytułu tekstu nie uwzględnił znaku-koncepcji yong ze względu na jego wieloznaczność i wielość interpretacji wysuwanych zarówno przez badaczy zachodnich, jak i chińskich (Legge). Według Słownika Języka Polskiego „doktryna” to „system poglądów, twierdzeń i założeń z określonej dziedziny wiedzy"2. Biorąc pod uwagę nastawienie na sytuacyjność oraz relatywizm wczesnej chińskiej myśli, trudno uznać to, co zapisano w Zhong Yongu, za doktrynę - zasady postępowania są bowiem, zgodnie z koncepcją czynienia wszystkiego we właściwym momencie shizhong, różne dla osób znajdujących się w odmiennych okolicznościach ${ }^{3}$. Słowo „doktryna” zostało uznane za zachodnią nadinterpretację tytułu i zawartości tekstu, dlatego w ostatnich latach podejmowano próby przełożenia frazy zhong yong w sposób bardziej adekwatny. Roger T. Ames i David L. Hall zaproponowali całkowicie odbiegające od tradycyjnego tłumaczenia sformułowanie $\mathrm{Focu}$ sing on Familiar ${ }^{4}$. Tu Wei-ming zatytułował swój, oparty na komentarzu

podkreślał znaczenie uczucia, lecz także intuicji, która według niego łączyła skończoność z nieskończonością. Por. Otto 10-13.

${ }^{2}$ Słownik Języka Polskiego, https://sjp.pwn.pl/sjp/doktryna;2555292.html, dostęp 21.12.2020.

${ }^{3} \mathrm{~W}$ Zhong Yong mówi się, że ,zhong yong człowieka moralnie doskonałego junzi polega na robieniu wszystkiego we właściwym momencie” (君子之中庸也、君子而 時中).

${ }^{4}$ Według Chengyanga Li jest to tłumaczenie błędne, jako że Hall i Ames użyli dwóch różnych znaczeń pojęcia yong, ponieważ zhong nie można interpretować jako focusing. 
Zhu Xi, przekład jako Centrality and commonality, natomiast Andrew Plaks jako Practice of the Mean. W jedynym, jak dotąd, polskim przekładzie tekstu Anna Iwona Wójcik pozostawiła w tytule słowo „doktryna”, co nie przyczyniło się w żaden sposób do zmiany stanu badań ${ }^{5}$, podobnie jak reszta jej przekładu, stąd decyzja o zaprezentowaniu własnych fragmentów tłumaczeń, które odpowiadają mojej interpretacji tekstu.

Zhong Yong można podzielić na części tematyczne: w rozdziale 1 pojawia się klaster pojęć niebo tian, zhong ${ }^{6}$ i harmonia he, wskazane są także wzajemne zależności między nimi ${ }^{7}$. Niebo jest źródłem naturalnych dyspozycji, których rozwijanie jest właściwym sposobem działania człowieka. Właściwe postępowanie oraz wyrażanie emocji są źródłem harmonii he. Jeśli na świecie (tianxia) zapanuje harmonijny ład, wszystkie rzeczy będą prosperować. W Zhong Yong stwierdza się zatem, że ludzka psychika i jej dobrostan ma bezpośredni wpływ na funkcjonowanie świata. Stąd potrzeba bezustannego samodoskonalenia i postępowania zgodnie z nauczaniem moralnym (jiao).

Kolejne rozdziały zawierają opis postępowania wzoru osobowego - człowieka moralnie doskonałego junzi, jego przeciwieństwa, antywzoru - prostaka xiaoren oraz ich rozumienia postępowania zgodnego z zhong yong. Co ważne, w tekście nie pojawia się definicja tej koncepcji, lecz jedynie skutki działania zgodnie z nią i do niej przeciwnie (2-11). Dalsza część tekstu zawiera rozdziały mówiące o tym, że człowiek moralnie doskonały (junzi) powinien czerpać wzorce postępowania ze społecznego ludzkiego świata. Właściwe zachowania przejawiają się w codziennym porządku i są związane z empatyczną wrażliwością na innych (shuzhong), a także z posłuszeństwem xiao, postępowanie zatem człowieka moralnie doskonałego polega na zaprowadzaniu ładu w społeczeństwie, nie zaś na bezrefleksyjnym naślado-waniu tego, co uzna za porządek nieba tian (12-16). Rozdziały 17-20 zawierają wypowiedzi Konfucjusza o cnotliwych władcach - Shunie, królach Zhou, a także ciągłości ich rządów, wyrażającej się w kontynuowaniu woli przodków, składaniu im ofiar i posłuszeństwie xiao wobec nich. Rozdział 20 jest poświęcony właściwemu rządzeniu i ma strukturę podobną do części innego rozdziału Zapisków o Rytuale - Da Xue - właściwe rządzenie jest związane z samodoskonaleniem się władcy i elit, z podtrzymywaniem pięciu relacji oraz wypełnianiem obowiązków związanych z rolami społecznymi.

\footnotetext{
${ }^{5}$ Doktryna Środka 337-350.

${ }^{6} \mathrm{~W}$ początkowej części artykułu nie będę przekładać pojęć zhong i yong. Pozostanę przy zapisie transkrypcją pinyin.

${ }^{7}$ Numeracja rozdziałów Zhong Yongu za układem tekstu podanym na stronie ctext.org, dostęp 13.01.2021.
} 
Rozdziały 21-26 zawierają opis samodoskonalenia na poziomie jednostki pojawia się $\mathrm{w}$ niej koncepcja cheng, zwykle tłumaczona jako sincerity, authenticity lub integrity ${ }^{8}$. W rozdziałach 26 i 27 przedstawiono sposób działania nieba tian i ziemi $d i-\mathrm{w}$ jaki sposób funkcjonują i dokonują transformacji. W rozdziale 28 dokonuje się zmiana narracji - filozoficzna refleksja nad sposobami funkcjonowania natury oraz społeczeństwa zostaje zastąpiona opisem czasowej i przestrzennej nieskończoności, w którą wkracza konfucjański mędrzec shengren, osiągnąwszy doskonałość moralną. Niebo i ziemia w swym ogromie powodują, że wszystkie rzeczy mogą istnieć - mędrzec i jego siła moralna mają podobną sprawczość, choć nie należy wykluczać, że opis ten jest hiperbolą ${ }^{9}$ Końcowa część tekstu (rozdziały 30-33) zawiera wyidealizowaną wizję przeszłości jako czasu, w którym na ziemi i niebie panował ład moralny i harmonia, dzięki czemu mogły dokonywać się stosowne transformacje ${ }^{10}$. Rządy Pierwszych Władców oraz królów Zhou stanowią wzorzec dla każdego późniejszego władcy - dzięki kontynuacji ich sposobu sprawowania władzy wszyscy zostają włączeni w quasi-religijną wspólnotę kulturową, przekraczając tym samym fizyczne ramy swojego istnienia. Poprzez nawiązanie do porządku wykraczającego poza ludzki świat i jego intuicyjnego poznania Zhong Yong staje się nie tylko instrukcją społeczno-polityczną, lecz także, przynajmniej w części, tekstem opisującym doświadczenie religijne ${ }^{11}$.

Zhong Yong przedstawia opis trzech porządków: naturalnego (天之道, 天 地之道, 誠), ludzkiego/społecznego, który ma naśladować naturalny (聖人之 道, 君子之道,人之道也, 誠之) oraz porządek świata mędrca shengrena (聖 人之道). Porządek ludzki/społeczny ustanawia się przez właściwe rządy (人 道敏政，地道敏樹。夫政也者，蒲盧也), ustanawianie zaś właściwych rządów, co oznacza - rządów sprawowanych przez cnotliwego władcę, któremu społeczeństwo poddaje się bez stosowania przymusu - odbywa się za pomocą posłuszeństwa xiao. Porządek naturalny/integralność cheng nieba

\footnotetext{
${ }^{8}$ Koncepcja cheng jest jedną z kluczowych w Zhong Yong, nie jest jednak istotna dla thumaczenia tytułu, dlatego w tym artykule pozostawiam ją bez szerszego omówienia. Por. Pejda, Concepts 317-326.

${ }^{9}$ Wiele wskazuje na to, że przynajmniej część przypisywanej Konfucjuszowi wypowiedzi, która znalazła się w rozdziale 29, została dodana po zjednoczeniu Qin - wspomniano w nim o ujednoliceniu miar oraz pisma, a także rozstawu kół w wozach, co dokonało się właśnie po zjednoczeniu kraju przez pierwszego cesarza.

${ }^{10}$ Por. podział tekstu Roberta Eno (scholarworks.iu.edu/dspace/handle/2022/23424, dostęp 20.12.2020)

${ }^{11}$ Poznawanie świata jest w Zhong Yong częściowo oparte na intuicji, która „uznając rzeczy zmysłowe, pozwala nam dochodzić do duchowych i tworzyć związek między nimi” (Keller 15).
} 
i ziemi jest immanentną ich cechą, podczas gdy integralność człowieka musi zostać osiągnięta poprzez pielęgnowanie właściwych dyspozycji i samodoskonalenie (天命之謂性。率性之謂道。修道之謂教 ${ }^{12}$ ). Transmisja wzorców postępowania przebiega w Zhong Yong zarówno poziomo, jak i pionowo. Przekaz poziomy pochodzi od dawnych królów, których kapitał kulturowy powinien ulegać dalszemu dziedziczeniu, przekaz zaś pionowy to rozwijanie właściwych dyspozycji, którymi obdarowało człowieka niebo tian. Obydwa przekazy muszą być realizowane przez całą społeczność wtedy i tylko wtedy można osiągnąć cel, którym jest harmonizowanie z niebem i ziemią.

Tytuł tekstu składa się z dwóch znaków-koncepcji i odnosi się do ludzkiego postępowania, ponieważ tylko ono może podlegać zmianie poprzez doskonalenie. Sfera natury jest uznana za funkcjonującą w sposób idealny i niewymagający zmian. Ostatecznym celem ludzkiego samodoskonalenia jest osiągnięcie stanu mędrca (shengren), który - podobnie jak niebo (tian) ma wpływ na transformacje w świecie (hua). Wywód przedstawiony w Zhong Yong nie pokrywa się z kolejnością rozdziałów - w początkowym akapicie znalazło się wprawdzie stwierdzenie, że źródłem naturalnego ładu, wzorcem, jest niebo, lecz uwaga czytelnika jest natychmiast skierowana na świat ludzi, na których spoczywa obowiązek samodoskonalenia. Ni Peimin słusznie konstatuje, że „fundamentalnym celem [Zhong Yong] nie jest opisać, jaki jest świat, lecz raczej poinstruować ludzi, jak mają żyć" (Ni 190). Stąd tekst nie zawiera obszernego namysłu nad tym, jaka jest natura nieba, lecz raczej jak funkcjonuje, jakie zachodzą w niej zmiany i jak człowiek może włączyć się w jej aktywność. Świat zewnętrzny dostarcza okazji do nawiązania z nim wzajemnie korzystnych relacji, a naturalnym dla człowieka środowiskiem, w którym może się realizować natura (xing), jest społeczeństwo. Stosowanie się do instrukcji (jiao) wykracza jednak poza ramy społeczne. Gdy człowiek rozwinie w sobie dyspozycje, które dało mu niebo, praktykuje posłuszeństwo wobec rodziny i dawnych władców (xiao), osiągnie integralność moralną (cheng), wtedy jego doświadczenie przestaje być jedynie działalnością ograniczoną poprzez czas i przestrzeń jego życia. Osiągnięcie pełni człowieczeństwa jest $\mathrm{w}$ tradycji konfucjańskiej projektem religijnym, który rozpoczyna się w warunkach zwykłej społeczności i w relacjach rodzinnych, jest kontynuowane poprzez rozszerzanie i rozwijanie tych połączeń, aż do

\footnotetext{
${ }^{12}$ Naturą zwie się to, co otrzymane zostało z nadania nieba. [Podążaniem] drogą [naturalnego porządku] zwie się to, co jest zgodne z naturą. Kultywowanie drogi [naturalnego porządku] zwie się nauczaniem.
} 
stopnia osiągnięcia takiego wpływu na otoczenie, który umożliwia dokonywanie przemian i ulepszania własnego świata, podobnie jak to się dzieje w świecie natury (Wong 49).

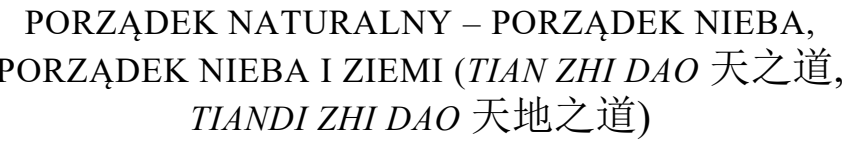

W Analektach odnotowano, że niebo jest niemą siłą, która powoduje, że świat zewnętrzny funkcjonuje we właściwym porządku ${ }^{13}$. W Zhong Yong działanie nieba przedstawiono w podobny sposób:

[...] rzecz zrodzona przez niebo jest przez nie obdarowana w zależności od jej właściwości. Dlatego [niebo] odżywia to, co rośnie, i obala, to co się chyli [ku upadkowi].

天之生物, 必因其材而篤焉。故栽者培之,傾者覆之

Najobszerniejszy opis funkcjonowania świata zdaje się sugerować, że nawet niewielkie elementy - współdziałające ze sobą cząstki są w stanie włączyć się w transformacje, których oddzielnie nie dałyby rady przeprowadzić. Przytaczam ten długi, lecz istotny, fragment w całości:

Sposób [działania] nieba i ziemi może zostać wyczerpująco opisany jednym zdaniem: nie ma w nich dwoistości i dlatego generują rzeczy w sposób niezgłębiony. Sposób [działania] nieba i ziemi jest szeroki i namacalny, wniosły i jaśniejący, dalekosiężny i długotrwały.

To oto niebo jest wielością świateł, ale ich niezmierzoność powoduje, że słońce, księżyc, gwiazdy i konstelacje są przez nie podtrzymywane i rozciągają się nad wszystkimi rzeczami.

Ta oto ziemia jest wielością pojedynczych stożków gleby, ale ich przepastność podtrzymuje góry Hua i Yue, nie odczuwając ich ciężaru, unoszą na sobie rzeki i morza, zaś te nie wypływają na zewnątrz, ziemia podtrzymuje wszystkie rzeczy.

Te oto góry są wielością pojedynczych kamieni, ale w swym ogromie, [umożliwiają] wegetację traw i drzew, zamieszkują je ptaki i zwierzęta, skrywają powstające w nich drogocenne kamienie.

Ta oto woda jest wielością pojedynczych kropli, lecz w ich niezmierzoności rodzą się żółwie morskie, jaszczury, smoki i ryby, mnożną się [dzięki niej] zasoby i bogactwa.

${ }^{13}$ „Czy niebo tian mówi? Cztery pory roku następują po sobie, wszystkie rzeczy powstają, ale czy niebo mówi? (天何言哉? 四時行焉, 百物生焉, 天何言哉?)”. (Konfucjusz, Analekta, thum. K. Pejda, XVII.19, s. 189). 
天地之道，可壹言而盡也。其為物不或，則其生物不測。

天地之道，博也厚也，高也明也，悠也久也。

今夫天, 斯昭昭之多, 及其無窮也, 日月星辰系焉, 萬物覆焉。

今夫地, 一撮土之多, 及其廣厚, 載華岳而不重, 振河海而不泄, 萬物載焉。

今夫山, 一拳石之多, 及其廣大, 草木生之, 禽獸居之, 寶藏興焉。

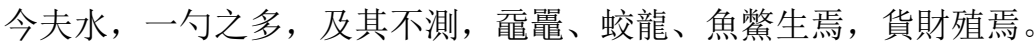

Z powyższego opisu jasno wynika, że Zhong Yong nie zawiera, jak to określił Plaks, „objaśnienia abstrakcyjnej uniwersalnej idei na potrzeby konkretnego ludzkiego działania" (Plaks 78), lecz raczej opis konkretnych działań natury i przeniesienia ich do świata ludzi, adekwatnie do ludzkich możliwości.

Kluczowe w tym fragmencie jest słowo „wielość” (duo 多) - pojedyncza kropla, kamień lub piędź ziemi to niewiele znaczące elementy. Ich siła zaczyna przejawiać się właśnie w wielości - wtedy tworzą oceany, góry, wszystko to zaś jest podtrzymywanie przez ziemię. Trudno oprzeć się wrażeniu, że opis ten znalazł się w Zhong Yong po to, aby wskazać ludziom, że mają działać podobnie. Jeden człowiek może niewiele, lecz społeczeństwo zorganizowane i rządzone przez cnotliwego władcę stanowi właściwie działający element świata - może wtedy stanowić trójnię z niebem, ziemią i brać udział w zachodzących na świecie przemianach, a także reprodukować wzory kultury ustanowione przez Pierwszych Władców.

Integralność - kompletność i współdziałanie wszystkich elementów w naturze - cheng nieba / ład dao nieba [誠者、天之道也] jest czymś naturalnym i bezwysiłkowym. Wszystko działa w sposób niezakłócony, powodując bezustanne transformacje rzeczy.

\section{PORZĄDEK ŚWIATA LUDZI \\ (JUNZI ZHI DAO, REN ZHI DAO 君子之道, 人之道也)}

Michael Puett twierdzi, że w Zapiskach o Rytuale Li Ji, których Zhong Yong jest częścią, wyrażono następującą myśl: zanim ludzie rozpoczęli swoją kulturową aktywność, na świecie panował pierwotny ład, ludzie zaś żyli jak zwierzęta (mieszkali w jaskiniach lub gniazdach, jedli surowe jedzenie). Królowie-mędrcy nauczyli ludzi, jak budować domostwa, używać ognia i uprawiać ziemię, zrywając tym samym intymną więź człowieka i natury. Tekst wyraża zatem potrzebę powrotu do życia zgodnego z dao - bez utraty osiągnięć, które przyczyniły się do rozwoju ludzkości, lecz poprzez zasto- 
sowanie rytuałów. Rytuały miały przywrócić inny rodzaj ładu - harmonię, w której tworzeniu uczestniczyć będą ludzie, a w której centrum będą znajdować się mędrcy. Taki rodzaj harmonii nie istniał wcześniej i nie był to porządek, który należało odtworzyć, lecz który należało wytworzyć (Puett 125-126).

$\mathrm{Na}$ poziomie zarządzania państwem harmonia mogła zostać osiągnięta poprzez respektowanie dziewięciu zasad postępowania. Ci, którzy władali krajem, powinni:

[...] doskonalić się, okazywać szacunek szlachetnym, kochać swój klan, poważać wysokich ministrów, cenić sobie [służbę] ministrów, traktować lud jak [własne] dzieci; zachęcać rzemieślników, żeby przybywali [do państwa], ludzi z daleka traktować przyjaźnie, hołubić arystokrację".

修身也、尊賢也、親親也、敬大臣也、體群臣也、子庶民也、來百工也、柔 遠人也、懷諸侯也

Samodoskonalenie było punktem wyjścia do zaprowadzania ładu w kraju. Każdy człowiek był zobowiązany do nauki stosownego zachowania, aby móc wypełniać obowiązki związane $\mathrm{z}$ rolami społecznymi. Istotą samodoskonalenia była nauka właściwego wyrażania emocji. W początkowej części Zhong Yong zapisano:

Nim pojawią się radość, gniew, żal i radość, [stan taki] zowie się wewnętrznym ${ }^{14}$. Gdy już się pojawią [one] i są stosownie uregulowane ${ }^{15}$, [stan taki] zowie się harmonijnym. To, co [istnieje] we właściwym [stopniu], jest wielką podstawą wszystkiego na ziemi. To, co [jest] harmonijne, stanowi niekończącą się drogę. Osiągnąwszy właściwą harmonię, niebo i ziemia znajdują się w odpowiednim miejscu, a wszystkie rzeczy prosperują.

喜怒哀樂之未發, 謂之中; 發而皆中節, 謂之和; 中也者, 天下之大本也; 和 也者, 天下之達道也。致中和, 天地位焉, 萬物育焉

W innym rozdziale Zapisków - Li Yun wspomina się o tym, że wszyscy posiadają emocje, zaś do ich ujarzmienia powinny służyć ustanowione przez

\footnotetext{
${ }^{14}$ Jest tym, co w środku.

${ }^{15}$ Li twierdzi, że jie 節 ma tutaj podobne znaczenie, co w Analektach I.12: „Najcenniejszym efektem [przestrzegania] norm obyczajowych jest harmonia społeczna. To jest właśnie najpiękniejsza z dróg, którą podążali Pierwsi Królowie, mniejsze i większe sprawy jedynie jej towarzyszą. Jednak to się nie zawsze udaje - są tacy, którzy wiedzą [jedynie, co to jest\} równowaga [społeczna] i układają się ze wszystkimi, lecz nie znają norm obyczajowych i wtedy właśnie się to nie udaje (禮之用, 和為貴。先王之道斯為美, 小大由之。有所不行, 知和而和, 不以禮 節之, 亦不可行也)” (Konfucjusz, Analekta, tłum. K. Pejda, 25).
} 
władców-mędrców rytuały (故聖王修義之柄、禮之序, 以治人情) ${ }^{16}$. Ludzie powinni realizować swoje dao w społeczności poprzez podtrzymywanie harmonijnych relacji z innymi oraz wypełnianie obowiązków narzuconych przez role społeczne. Właściwe postępowanie człowieka polegać miało także na naśladowaniu integralności/kompletności nieba [誠之者、人之道也]. W przeciwieństwie do natury i nieba integralność owa nie była u ludzi wrodzona osiągnięcie jej wiązało się z inteligentnym samorozwojem oraz bezustanną uwagą, aby podążać drogą środka - drogą tego, co stosowne w określonej sytuacji:

Integralność to sposób postępowania nieba, uczynienie integralnym samego siebie to sposób postępowania człowieka. Integralność to [trafianie w] środek bez wysiłku i pojmowanie [wszystkiego] bez namysłu. Podążać bez wysiłku drogą środka, [to właśnie oznacza] być mędrcem.

誠者、天之道也。誠之者、人之道也。誠者不勉而中、不思而得、從容中道、 聖人也。

Paradoksalnie - nauka bezwysiłkowego działania wymagała od człowieka znacznego wysiłku. Ponadto zadania, przed którymi stawał człowiek, były zupełnie odmienne od wykonywanych naturalnie i bezwysiłkowo obowiązków nieba. Jako że człowiek posiada ciało i uczucia, ma rodziców, żyje w społeczeństwie, w związku z tym jego obowiązkiem jest właściwe wyrażanie emocji, utrzymywanie dobrych relacji z rodziną, jeśli zaś jest władcą - humanitarne rządy, oraz utrzymywanie na świecie harmonii. Można to osiągnąć w jeden tylko sposób: praktykując drogę środka, która jest odwzorowaniem integralności, bezwysiłkowości oraz ładu nieba na ziemi. W Zhong Yong, podobnie jak w innych tekstach Czteroksięgu, zapisano, że każdy posiada w swej naturze naturalne dyspozycje do stania się mędrcem. Odnalezienie ich w sobie i niezłomne rozwijanie jest celem życia dla każdego człowieka ${ }^{17}$.

${ }^{16}$ „Dlatego Królowie-Mędrcy kultywowali podstawy tego, co słuszne, oraz [właściwy] porządek rytuału, aby zarządzać ludzkimi emocjami”. Wczesna myśl konfucjańska wyrażała przekonanie, że człowiek osiąga pełnię człowieczeństwa, gdy jego pierwotne impulsy zostają okiełznane przez rytuały $l i$. Postępowanie zgodne z $l i$ nie jest jedynie formalistyczną dehumanizacją. Por. Fingarette 7.

17 „Ten, kto chce uczynić samego siebie integralnym, wybiera [to, co jest jego] dobrymi dyspozycjami i mocno się tego trzyma. Szeroko się o nich uczy, szczegółowo je zgłębia, uważnie nad nimi deliberuje, dokonuje jasnych rozróżnień i uczciwie praktykuje. (誠之者、擇善而固執 之者也。博學之、審問之、買思之、明辨之、篤行之)”. 


\section{PORZĄDEK ŚWIATA MĘDRCA SHENGREN (聖人之道)}

Wiele wskazuje na to, że Zhong Yong, podobnie jak pozostałe rozdziały $L i J i$, nie jest jedynie filozoficznym rozważaniem na tematy społeczne. W rozdziale 25 tekstu zaznaczono, że po osiągnięciu integralności moralnej człowiek staje się podobny temu, co w Zapiskach o Rytuale określa się jako duchy shen (至誠如神) ${ }^{18}$. Tekst dotyka zatem zagadnień, które nie były poruszane w tak szerokim zakresie w innych częściach Czteroksięgu - tego, że poprzez swoją inteligencję, samorozwój oraz staranne wypełnianie obowiązków związanych z rolami społecznymi, osiągnąwszy integralność moralną, mędrzec staje się łącznikiem między niebem tian oraz światem ludzi, posiada także intuicję, która według Rudolfa Otto pozwala poznawać to, co nieskończone i wymykające się poznaniu racjonalnemu (至誠之道, 可以 前知 ) (Otto 15). Trudno zgodzić się z Rogerem T. Amesem, który twierdzi, że poczucie religijności obecne w konfucjanizmie nie wykracza poza ludzkie doświadczenie. Owo poczucie ma wprawdzie źródło w tym, co Henry Rosemont i Roger T. Ames określają jako ,znajdowanie spełnienia w relacjach rodzinnych i przyjacielskich, ich wzajemności" (Rosemont i Ames 126), lecz w Zhong Yong wspomina się o mędrcu, który jest podobny niebu, zaś swoją działalnością wykracza poza ograniczenia narzucone zwykłemu człowiekowi przez jego cielesność i czas trwania życia. Usilne pozbawianie wczesnej myśli konfucjańskiej elementów religijnych zasadniczo ją zubaża. Zhong Yong nie prezentuje oczywiście religijnej myśli teistycznej, lecz raczej doświadczenie religijne, które Rudolf Otto określił jako wyraz uczuć podziwu i trwogi wobec potęgi natury: „pewne symbole, jak ogrom pustyni, głębia nocy wywołują oddźwięki specyficznie religijne (odczucie numinosum), które nie mogą być sprowadzone do żadnych kategorii świadomości" (Otto 15). Nie ma powodu, by twierdzić, że wczesne społeczeństwo chińskie było takich uczuć pozbawione, jego zaś funkcjonowanie ograniczało się jedynie do budowania relacji międzyludzkich.

Michael Puett (212) zauważył, że rolą rytuałów opisanych także w pozostałych rozdziałach Zapiskówo Rytuale Li Ji jest zmiana świadomości ich uczestników, którzy biorąc w nich udział, stają się ogniwem kontynuacji pokoleniowej. Podobną rolę odgrywała koncepcja posłuszeństwa xiao, które

\footnotetext{
${ }^{18}$ „Góry i lasy, rzeki i doliny, pagórki i szczyty, które mogą wydawać z siebie chmury, wiatr i deszcz, i powodują anomalie, na wszystkie mówi się shen”山林、川谷、丘陵, 能出云為風 雨, 見怪物, 皆曰神. Tłumaczenie za Puettem (210). Mircea Eliade z kolei twierdzi, że w Chinach natura nigdy nie została zdesakralizowana. Por. Eliade 125
} 
w Zhong Yongu nie ogranicza się jedynie do służenia rodzicom, lecz wszystkim przodkom poprzez składanie stosownych ofiar:

Mistrz powiedział: „Jak dalece posłuszni wobec woli ojców byli król Wu i książę Zhou. Posłuszeństwo xiao to nic innego, jak przodowanie w wypełnianiu ich woli, przodowanie w przekazywaniu ich spraw. Wiosną i jesienią odnawiali świątynie przodków, ustawiali $\mathrm{w}$ rzędzie ich naczynia ofiarne, prezentowali rytualne szaty i składali $\mathrm{w}$ ofierze sezonowe posiłki. Przy pomocy rytuałów [odprawianych w] świątyniach przodków, ustalali lineaże porządku zhaomu ${ }^{19}$. [Utrzymując] właściwy porządek tytularny, odróżniali zamożnych od biedoty, [utrzymując] właściwą kolejność obrządku, wyróżniali szlachetnych. [...]

Zajmując swoją pozycję, przeprowadzając rytuały, odgrywając swoją muzykę, oddając należne honory tym, którym należy się szacunek, miłując [ludzi] z własnego klanu, w taki sposób służyli umarłym, tak jakby służyli im za życia; służyli, tym którzy odeszli, tak jakby byli oni wśród żywych - oto najwyższy [stopień] posłuszeństwa xiao.

Odprawiając rytuały przy ołtarzu boga ziemi, służą najwyższemu bóstwu, odprawiając rytuały przy ołtarzach przodków, czczą swoich przodków. Ten, kto pojął znaczenie rytuałów przy ołtarzu boga ziemi oraz ofiary di, dla tego rządzenie państwem będzie tak proste, jak spojrzenie na swą własną dłoń ${ }^{20}$.

子曰。武王、周公、其達孝矣乎。夫孝者。善繼人之志、善述人之事者也。

春、秋修其祖廟、陳其宗器、設其裳衣、薦其時食。宗廟之禮、所以序昭穆

也。序爵、所以辨貴賤也。序事、所以辨賢也。

[…] 踐其位、行其禮、奏其樂、敬其所尊、愛其所親、事死如事生、事亡如事 存、孝之至也。郊社之禮、所以事上帝也。宗廟之禮、所以祀乎其先也。明乎 郊社之禮、禘嘗之義、治國其如示諸掌乎。

Konfucjańskie poczucie kontynuacji dzieła przodków, ich rytuałów, włączało każdego uczestnika do wspólnoty przekraczającej ramy czasowe i geograficzne, trudno zatem uznać, że nie jest to rodzaj specyficznie pojmowanej transcendencji. Oczywiście w największym stopniu korzystali z niej ci, którzy mieli świadomość owej kontynuacji - mędrcy. Tacy ludzie stawali się połączeniem między światem żywych, światem przodków oraz duchami natury.

${ }^{19}$ Powitanie duchów poszczególnych przodków, i to w ściśle określonej kolejności, zgodnie z tzw. porządkiem zhaomu 昭穆. Porządek ten został naruszony, poczynając od, „wyniesienia na ołtarze" księcia Xi 僖 (659-627 p.n.e.).

${ }^{20}$ Podobny wniosek pojawia się w Analektach w rozdziale III.11, a wywód podobny w swym sensie do zacytowanego fragmentu pojawia się także w księdze Xunzi w rozdziale Li Lun 


\section{ZNACZENIE FRAZY ZHONG YONG}

Li Chenyang słusznie podkreśla, że jedną z głównych koncepcji przedstawionych $\mathrm{w}$ analizowanym tekście jest harmonia he, stan równowagi, zarówno psychicznej, jak i społecznej. Stan ten jest możliwy do osiągnięcia, jedynie gdy ludzie praktykują postawę zhong.

Pojęcie zhong posiada kilka znaczeń:

- $\quad l i$ 里 lub nei 內 - w tym znaczeniu pojawia się w początkowym fragmencie tekstu: „nim pojawią się radość, gniew, żal i radość, [stan taki] zowie się wewnętrznym (喜怒哀樂之未發, 謂之中)” lub też we fragmencie: „wszyscy mówią '[posiadam] wiedzę', lecz gdy zostaną zwabieni w sieć, lub do środka pułapki, żaden nie wie, jak z nich uciec (人皆曰『予知』, 驅而納諸罟擭陷阱之中, 而莫之知辟也)”;

- ban 半, np. w Mozi zapisano: „zhong znajduje się w środku identycznych długości” (中, 同長也), podobne znaczenie to „średni, średnia" zhongdeng 中等. W Zhong Yong zapisano z kolei, że Shun: „dzierżył dwa krańce, środka używając do [rządzenia] ludem” - 執其 兩端，用其中於民；

- zhong w czwartym tonie posiada także znaczenie zbliżone do fuhe 符 合 - „stosować się do” lub he 合 - „być stosownym, odpowiednim”. W Zuo Zhuanie zapisano słowa Li Suna, który rzekł: „Syn Zijia wielokrotnie rozmawiał [o mnie z księciem], i zawsze trafnie przedstawiał moją wolę". 左傳·定元年》季孫曰: 子家子亟言於我, 未嘗不中吾 志也。(Xu 428-429)

W tekście znaleźć można wszystkie wymienione wyżej znaczenia zhong, zaś tłumaczenie pojęcia zhong w każdym kontekście jako „środek” jest błędne. Ponadto zhong nie jest cnotą samą w sobie - jest raczej metodą działania, czyli znajdowania właściwego środka/balansu/równowagi w każdej sytuacji. Fraza shijie 中節 pojawiająca się w początkowym fragmencie Zhong Yongu oznacza „we właściwym stopniu”. Shizhong 時中 to z kolei „działanie stosowne do momentu”, właściwy sposób, w jaki człowiek powinien postępować, lub też właściwy moment, w którym człowiek powinien postępować. Zhong dao 中道 „droga środka” to pragmatyczna postawa wobec świata oraz społeczeństwa, podkreślająca konieczność dostosowania subiektywnych ludzkich pragnień, dążeń i uczuć do obiektywnych sytuacji lub warunków. Według tego punktu widzenia, użyteczność i zgodność idei z rzeczywistością mają większe znaczenie niż ich teoretyczna poprawność lub rozumowanie logiczne. Już we wczesnych czasach rozwoju myśli chińskiej 
uznano, że rozważania teoretyczne są niewiele warte, jeśli nie pomagają osiągać realnych celów w konkretnych sytuacjach społecznych. Połączona $\mathrm{z}$ ideą zhong dao idea shi zhong zakłada zachowania, które zmieniają się i są stosowne do sytuacji, w jakiej znalazła się osoba. Zhong jako sposób zaprowadzania ładu i harmonii $\mathrm{w}$ społeczeństwie to postawa jednocząca i łącząca niejednokrotnie odległe od siebie potrzeby społeczne w celu poszukiwania kompromisu. W znaczeniu politycznym zhong dao polega na poszukiwaniu rozwiązań satysfakcjonujących przeciwników politycznych, unikaniu rozwiązań siłowych. W harmonijnie funkcjonującym społeczeństwie wszystkie grupy społeczne: elity i lud, biedni i bogaci, rząd centralny i lokalne władze poszukują zhong - wspólnych wartości, dzięki którym społeczeństwo to może się rozwijać, każdy zaś jego członek czerpać korzyści $\mathrm{z}$ tego rozwoju $(\mathrm{Xu})$.

Według wczesnych tekstów i komentatorów 庸 oznacza tyle, co „używać”, „zwykły, zwyczajny”平常 lub „powszechny” (Ni 194).

Robert Eno zauważył, że pojęcie yong dość precyzyjnie omówiono w tekście Zhuangzego:

Podział to kompletność, kompletność to rozpad. Wszystkie rzeczy nie są ani kompletne, ani w rozpadzie, lecz bezustannie przenika je jedność. Tylko ten, kto osiągnął [pełnię] wie, że przenika je jedność. Nie używa stronniczego [osądu], lecz szuka schronienia w tym, co powszednie. To, co powszednie [sprawdza się] w użyciu, [właściwe] użycie wynika z powszechności, powszechność sprawia, że osiąga się [jedność $]^{21}$.

其分也, 成也; 其成也, 毀也。凡物無成與毀, 復通為一。唯達者知通為

一, 為是不用而寓諸庸。庸也者, 用也; 用也者, 通也; 通也者, 得也。

Według Zhuangzego yong oznacza powszednią, sprawdzającą się w działaniu praktykę, która jest powszechnie stosowana.

W komentarzu do tekstu Zheng Xuan stwierdza, że ,yong oznacza “posiadać stałość'” (庸有常也). W komentarzu He Yana do Analektów znalazł się zapis: „yong oznacza 'stały'. Zhonghe oznacza jest dyspozycją, którą można praktykować stale” (庸常也中和可常行之德也). Z kolei Zhu Xi interpretował yong jako ,zwykły, zwyczajny” 平常. W Analektach VI. 29 czytamy jednak, że zhong yong to dyspozycja rzadko spotykana wśród ludu (中 庸之為德也，其至矣乎！民鮮久矣), o trwałości zatem nie może być mowy. Zhong Yong z kolei podaje:

${ }^{21}$ Tłumaczenie własne. Por. Zhuangzi, Prawdziwa Ksiega Południowego Kwiatu, thum. M. Jacoby, 36 . 
Droga człowieka moralnie doskonałego bierze swe początki [z poczynań zwykłych] mężów i niewiast, lecz gdy osiąga pełnię, przenika niebo i ziemię”.

君子之道、造端乎夫婦、及其至也、察乎天地。

W przypadku yong może zatem początkowo chodzić nie tyle o powszechność i stałość, co o powszedniość. Yong to codzienne wykonywanie swoich obowiązków - troska o rodziców i krewnych, opieka nad dziećmi, szacunek dla autorytetów i pomoc przyjaciołom. Upowszechnienie tych dobrych codziennych praktyk to główne zadanie dla ludzi moralnie doskonałych - junzi.

Interesujące jest porównanie działania wzoru osobowego junzi i antywzoru - prostaka xiao rena:

Człowiek moralnie doskonały praktykuje zhong yong, prostak czyni przeciwnie. Człowiek moralnie doskonały zachowując się stosownie, zawsze czyni wszystko w odpowiednim momencie. Zachowanie zaś odpowiednie dla prostaka to czynienie tego, co jest zabronione, i odrzucanie obaw.

君子中庸, 小人反中庸。君子之中庸也, 君子而時中; 小人之中庸也, 小人 而無忌憚也

Człowiek moralnie doskonały junzi praktykuje zhong yong, zachowując się „stosownie do momentu”. Podejmuje zatem działanie, które zakłada rozpoznanie zewnętrznych okoliczności i uwzględnienie ich w swym postępowaniu. Jeśli chodzi o postępowanie prostaka xiao ren, opis znacznie się komplikuje. Prostakowi może jedynie wydawać się, że praktykuje zhong yong - efektem takiego działania nie będzie harmonizowanie $\mathrm{z}$ otoczeniem, lecz odrzucenie wszelkich subiektywnych wrażeń, że może on postępować niewłaściwie. Wynika to $z$ koncentracji na sobie i swoim ego ${ }^{22}$. Zhong yong nie jest zatem obiektywną zasadą, której stosowanie lub też niestosowanie jest łatwe do weryfikacji. Jest to raczej wymagająca umiejętności odczytywania subtelnych sygnałów z otoczenia, „metodologia” postępowania, jej zaś skuteczność można rozpoznać dopiero po efektach działania ${ }^{23}$.

\footnotetext{
${ }^{22}$ Por. także ,prostak xiao ren zachowuje się gwałtownie licząc na szczęśliwy traf” (小人行險以敫幸).

${ }^{23}$ Główne aspekty samodoskonalenia konfucjańskiego xiushen obejmowały m.in. trening psychologiczny, który miał na celu wykształcenie niektórych kompetencji związanych z inteligencją emocjonalną. Daniel Goleman wyróżnił trzy główne grupy kompetencji emocjonalnych: kompetencje psychologiczne, do których zalicza się m.in. samoświadomość w znaczeniu umiejętności rozpoznawania własnych stanów emocjonalnych, wiedzy o własnych uczuciach, wartościach, preferencjach, możliwościach i ocenach intuicyjnych, czyli świadomość emocjonalna, oraz samokontrola; kompetencje emocjonalne: m.in. empatia oraz umiejętność współpracy z innym; kompetencje
} 
W wypadku większości tytułów rozdziałów Zapiskówo Rytuale $L i \quad J i$ pierwszy ze znaków jest określeniem do drugiego. Zakładając, że Zhong Yong nie stanowi wyjątku i że zhong jest określeniem do yong, uważam, że najwłaściwszą interpretacją frazy zhong yong jest „powszednie [praktykowanie], tego, co stosowne [aby osiągnąć harmonię]", ponieważ przekład ten oddaje relatywizm wczesnej myśli społecznej, a także jej pragmatyzm, wyraża także główną myśl tekstu - wytworzenie na świecie harmonii he. Jednocześnie zdaję sobie sprawę, że przekład ten jest zbyt długi, aby stać się tytułem, będę zatem umieszczać go w przypisie, pozostając przy zapisanej transkrypcją pinyin frazie Zhong Yong.

\section{BIBLIOGRAFIA}

Ames, Roger T., i David L. Hall. Focusing on Familiar: A Translation ad Philosophical Interpretation of Zhong Yong. University of Hawaii Press, 2001.

„Doktryna Środka”. Tłum. Anna Iwona Wójcik. Filozofia Wschodu, Wybór tekstów, red. Marta Kudelska, Wydawnoctwo UJ, 2013, ss. 337-350.

Eno, Robert. „The Great Learning and The Doctrine of the Mean: Translation, Commentary, and Notes". IUScholarWorks. scholarworks.iu.edu/dspace/handle/2022/23424. Dostęp 12.02. 2021.

Eliade, Mircea. Sacrum i profanum. O istocie religijności. Tłum. Robert Reszke. Wydawnictwo KR, 1996.

Fingarette, Herbert. Confucius: The Secular as Sacred, Waveland Press, 1972.

Keller, Józef. „Rudolf Otto i jego filozofia religii”. Rudolf Otto. Elementy irracjonalne w pojęciu bóstwa i ich stosunek do elementów racjonalnych. Tłum. Bogdan Kupis. Thesaurus Press, 1993, ss. 7-28.

Goleman, Daniel. Inteligencja Emocjonalna. Tłum. Andrzej Jankowski, Media Rodzina, 1997.

Konfucjusz. Analekta. Tłum. Katarzyna Pejda, Wydawnictwa Uniwersytetu Warszawskiego, 2018.

Legge, James. Confucian Analects, The Great Learning, and the Doctrine of the Mean. Dover Publications, 1971.

prakseologiczne: m.in. motywacja i zdolności adptacyjne. Kompetencji tych nabywa się w relacjach z innymi ludźmi. Konieczność przyswojenia kompetencji społecznych jest wyrażona we wszystkich tekstach zaliczanych do Czteroksięgu, także w Zhong Yong. Samodoskonalenie konfucjańskie rozpoczyna się od praktykowania posłuszeństwa wobec starszych xiao, oraz miłowania ludzi z własnego klanu qin, w Analektach mówi się o konieczności bezustannej refleksji nad własną postawą wobec innych sheng (I.4), a także o empatii shu, która niczym osnowa winna przenikać całe życie społeczne (IV.15), wspomina się o społecznych cechach miękkich (XVII.6). O kontrolowaniu własnych stanów emocjonalnych i zdolnościach przystosowawczych mówi się przy okazji klasterowej koncepcji zhong, m.in. w tekstach Mengzi oraz Zhong Yong. Zastosowanie w thumaczeniu słowa „doktryna”, w rozumieniu przedstawienia ustalonych a priori zasad, pozostaje w sprzeczności $\mathrm{z}$ omawianymi w Zhong Yong umiejętnościami elastycznej adaptacji do zastanych sytuacji społecznych i stoi w całkowitej sprzeczności z duchem tekstu. Por. Goleman 462-464. 
Li, Chenyang. „Zhongyong 中庸 as Grand Harmony - An Alternative Reading to Ames and Hall's Focusing the Familiar". Dao: A Journal of Comparative Philosophy, vol. 3, 2004, ss. 173188. Doi: 10.1007/BF02856661. Dostęp 10.01.2021.

$\mathrm{Ni}$, Peiming. „Reading Zhongyong as a gongfu instruction: Comments on Focusing the familiar”. Dao: A Journal of Comparative Philosophy, vol. 3, 2004, no. 2, ss. 189-203. www. academia.edu/6150028/Reading_Zhongyong_as_a_gongfu_instruction_Comments_on_Foc using the familiar_\%E4\%BB $\% 8 \mathrm{E} \% \mathrm{E} 5 \% 8 \mathrm{~A} \% 9 \mathrm{~F} \% \mathrm{E} 5 \% \mathrm{~A} 4 \% \mathrm{AB} \% \mathrm{E} 8 \% \mathrm{AE} \% \mathrm{BA} \% \mathrm{E} 7 \% 9 \mathrm{~A}$ $\% 84 \% \mathrm{E} 8 \% \mathrm{~A} 7 \% 92 \% \mathrm{E} 5 \% \mathrm{BA} \% \mathrm{~A} 6 \% \mathrm{E} 8 \% \mathrm{~A} 7 \% \mathrm{~A} 3 \% \mathrm{E} 8 \% \mathrm{AF} \% \mathrm{BB} \% \mathrm{E} 4 \% \mathrm{~B} \%$ AD\%E5\%BA \%B8_Dostęp 29.01.2021.

Otto, Rudolf. Świętość. Elementy irracjonalne w pojęciu bóstwa i ich stosunek do elementów racjonalnych. Tłum. Bogdan Kupis. Thesaurus Press, 1993.

Pejda, Katarzyna. „Concepts of xin 信 and cheng 誠 in early Confucian texts”. Oriental Languages and Civilizations, red. Barbara Michalak-Pikulska, Marek Piela i Tomasz Majtczak, Wydawnictwo UJ, 2020, ss. 317-326.

Pejda, Katarzyna. „Reintepretacja najważniejszych pojęć Dialogów Konfucjańskich. Klasterowy koncept Ren". Konfucjanizm i jego wspótczesne interpretacje, red. Roman Sławiński, CBKW IKŚiO PAN, 2013, ss. 64-75.

Plaks, Andrew H. Ta Hsueh and Chung Yung (The Highest Order of Cultivation and On the Practice of the Mean). Penguin Classics, 2003.

Puett, Michael. „Metaphysics in the ritual traditions of classical China”. Chinese Metaphysics and its problems, red. Chenyang Li i Franklin Perkins, Cambrigde University Press, 2015.

Rosemont, Henry, and Roger T. Ames. Confucian Role Ethics. A moral vision for $21^{\text {st }}$ Century? National Taiwan University, 2016.

Tu, Wei-ming. Centrality and Commonality: An Essay on Confucian Religiousness. A Revised and Enlarged Edition of Centrality and Commonality: An Essay on Chung-yung (SUNY series in Chinese Philosophy and Culture). State University of New York Press, 1989.y

Wong, Peter Y. J. „Toward Religious Harmony: A Confucian Contribution”. Confucianisms for a Changing World Cultural Order, red. Roger T. Ames and Peter D. Hershock, University of Hawaii Press, 2017.

$\mathrm{Xu}$, Keqian. „A Synthetic Comprehension of the Way of 'Zhong' in Early Confucian Philosophy. Frontiers of Philosophy in China, 7(3), 2012, ss. 422-438. Doi: 10.3868/s030-001012-0025-0.

Van Norden, Bryan W., „'Few Are Able to Appreciate the Flavours': Translating the Daxue and the Zhongyong”. Journal of Chinese Studies, no. 56, 2013, ss. 295-314.

Zhuangzi. Prawdziwa Księga Południowego Kwiatu. Tłum. Marcin Jacoby, Iskry, 2009.

\section{ZHONG YONG - KILKA UWAG O ZNACZENIU I TŁUMACZENIU TYTUŁU}

\section{Streszczenie}

Przedstawiona w tekście analiza dotyczy ogólnej myśli wyrażonej w Zhong Yong. Skupia się także na zbadaniu znaczenia znaków zhong, yong oraz na znaczeniu frazy, którą tworzą. Starożytny tekst przedstawia idealne działanie natury i nieba (tian) oraz sposoby na ich odtworzenie w społeczeństwie ludzkim. Istotą właściwego działania, które umożliwia tworzenie się i transformację rzeczy, jest harmonijnie funcjonująca wielość (duo) rzeczy - to wzór postępowania 
dla ludzi, którzy w harmonijnie działającym społeczeństwie mogą stanowić trójnię z niebem i ziemią. Autorka tekstu odnosi się także do tradycyjnego i najczęściej stosowanego przekładu tytułu „Doktryna Środka / Doctrine of Mean”, uznając go za nieadekwatny nie tylko ze względu na pominięcie w przekładzie znaczenia znaku yong, lecz także ze względu na nieuzwglęnienie w nim relatywizmu, którym charakteryzowała się wczesna myśl konfucjańska.

Słowa kluczowe: wczesna myśl konfucjańska; Zhong Yong; Doktryna Środka; samorozwój; konfucjańskie doświadczenie religijne. 